\author{
BULETINUL INSTITUTULUI POLITEHNIC DIN IAŞI \\ Publicat de \\ Universitatea Tehnică „Gheorghe Asachi” din Iaşi \\ Volumul 67 (71), Numărul 1, 2021 \\ Secţia \\ CONSTRUCȚII DE MAȘINI \\ DOI:10.2478/bipcm-2021-0007 \\ sciendo
}

\title{
INFLUENCE OF A REAL ESTATE CONSTRUCTION AREA WITH MIXED FUNCTIONS - TRAFFIC STUDY
}

BY

\section{ANDREI IONUT DONTUU*, TUDOR-MARIAN ULIAN and EDWARD RAKOSI}

\section{“Gheorghe Asachi” Technical University of Iaşi,} Faculty of Mechanical Engineering

Received: January 27, 2021

Accepted for publication: March 16, 2021

\begin{abstract}
Traffic studies are important because these provide significant information about traffic flows and traffic mobility in the area of study. Also, these studies can help to fluidize the traffic considering the actual number of cars and of the future cars which is estimated to increase due to considering traffic signals, roundabout or other traffic solutions. Traffic impact studies are important because the governmental agencies require them when a new building is developed as this can generate the increase of car traffic or can change the existing traffic paths. In this paper it will see how a new real estate construction area with mixed functions in the Miroslava village influence the traffic flow. This new building will lead to an increased the number of vehicles in the area and will change the existing traffic patterns, so it is required a traffic study.
\end{abstract}

Keywords: Cars; Traffic Jams; Traffic Monitoring; Traffic Fluidization; Traffic Pollution.

*Corresponding author; e-mail: andrei-ionut.dontu@academic.tuiasi.ro (c) 2021 Andrei Ionuț Donțu et al.

This is an open access article licensed under the Creative Commons Attribution-NonCommercialNoDerivatives 4.0 International License (CC BY-NC-ND 4.0). 


\section{Area Location and Characteristics}

Miroslava village is located near the eastern border of Romania, in the southwest of Iaşi - which, after the integration into the European Union, became an important city in the eastern part of Romania.

Documentary attested 586 years ago the whole village covers an area of $82.57 \mathrm{~km}^{2}$ and is the most developed village in Iasi county and according to the number of inhabitants it has a population of 11958 people. The village has an industrial park where several companies have developed working facilities.

The village of Miroslava is connected to the outside by the Iasi ring road, which is designated as a national road named DN28D. This road crosses the village in the north part. DJ248A is another road which connects the city of Iaşi with the village of Voinești and crosses the village from West to East, passing through the centre of Miroslava village. Also, through DJ248A is connected to Iasi International Airport, and to the main roads (E 58 and DN 248).

This paper analyses the implications on traffic flow in the area of Miroslava village, on Constantin Langa street (Voinești - Iași road), Vasile Alecsandri street and Arhitect Beldiman Filaret street as well as on the access roads in them, in the perspective of developing a real estate construction area with mixed functions services, as trade, public catering, outdoor space with a monument accommodation, park and above-ground parking.

The operation of the new complex, after completion of the works, will attract new flows of vehicles and pedestrians in the area, raising new issues regarding the connection to the street network and the road traffic of the village. These problems are generated by the precarious road infrastructure, insufficient and underdeveloped for the current requirements.

The issue of integrating the new construction in the current road traffic is put in the conditions in which it is expected as the engine index number in Romania will increase from 400 vehicles/1000 inhabitants to the European average of 600 vehicles/1000 inhabitants, in the next 10 years.

Regarding the public transportation, in the area proposed for investments there is a transport station on Constantin Langa Street, dedicated to stopping buses running on the Voinești - Iași route.

The solution we propose should solve more than taking over the flows of vehicles and pedestrians generated by ensuring the control of noise level and air pollution, by creating the premises to meet the growing need of traffic in the near future.

In Fig. 1 it can be seen the position of the new investment and the position in accord with Iași city.

The main public utility objectives in the immediate area of the study are: Constantin Langa street - DJ248A county road that ensures the road connection between Iasi city and Voinești village; office buildings with regime of local interest, implicitly the village mayor's office; Constantin Langa School. 


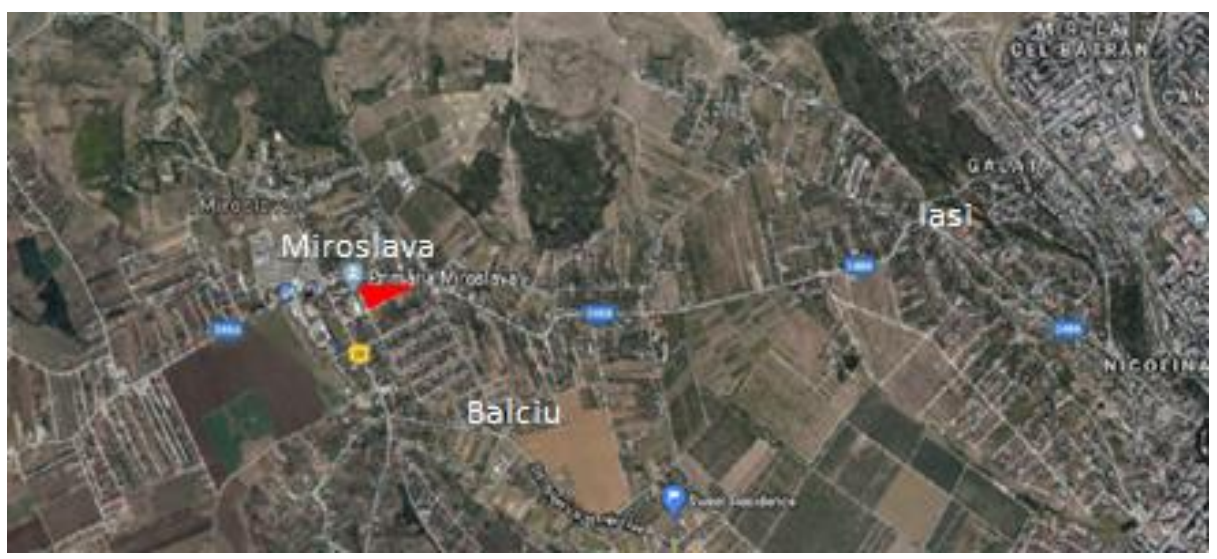

Fig. 1 - Positioning of the future investment.

County fleet of vehicles and the evolution of the degree of motorization over the time:

The car park of Iaşi County has registered a significant increase over the years. At the end of 2019, a number of 102058 vehicles were registered in addition to the end of 2016. The number of vehicles almost doubled.

The motorization rate, one of the indicators of sustainable development, can be determined as a ratio between the number of registered cars over the thousand inhabitants for Iaşi county:

$$
R_{\mathrm{Mj}}=247 \text { vehicles/1000 inhabitants }
$$

which is below the national average of 277 vehicles/1000 inhabitants. It must be taken into account that at the level of Iaşi Municipality the motorization rate is much higher than the average in the metropolitan area (Fig. 2).

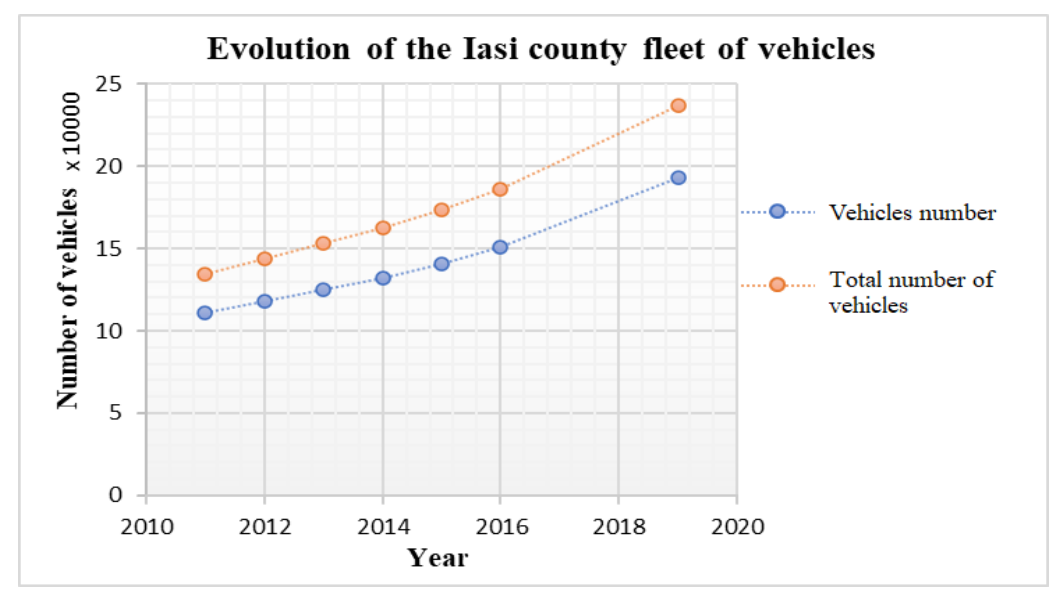

Fig. 2 - The evolution of the car park for Iaşi. 
The high degree of motorization in Iaşi Municipality, corroborated with a not very efficient public transport system and therefore unattractive for the population generates large volumes of traffic on the city's road networks. These large volumes of road traffic later spread to the main access areas in Iaşi, which leads to a general agglomeration of the metropolitan area and apparitions of traffic gems. It should be borne in mind that an increase of the number of road users also leads to increase the risk of accidents and a higher level of pollution (Dontu et al., 2016).

\section{Traffic Problems Identified in the Analysed Area}

The location of the new building is located on Constantin Langa Street in Miroslava Village, respectively in the perimeter delimited by Constantin Langa Street (Voineşti-Iaşi Road), Vasile Alecsandri Street and Arhitect Beldiman Filaret Street. The location is positioned in a well-defined perimeter of public roads, without inflections and dangerous curves, with a slight slope present on Vasile Alecsandri Street. All these streets, except Constantin Langa Street, have a low number of vehicles. The studied area is located in the central area of Miroslava village, in the vicinity of the town hall.

On the studied section of Constantin Langa Street there is a pedestrian crossing at the intersection with Vasile Alecsandri Street. It has deficiencies in marking and pre-signalling. The lack of road markings generates a high-risk factor that can affect road and pedestrian safety, and this is manifested throughout the analysed section. In the photos bellowed it can be seen the deficiencies.

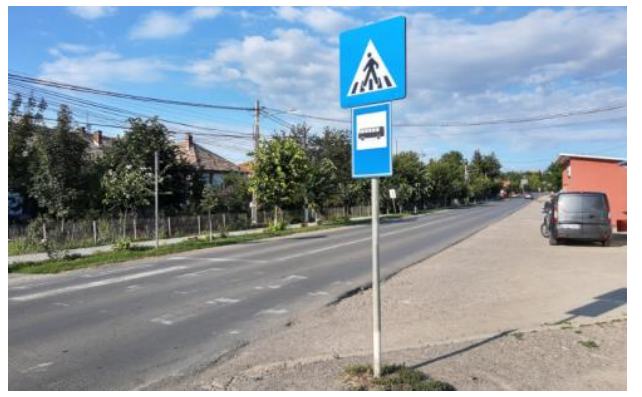

Fig. 3 - Pedestrian crossing at the intersection of Constantin Langa Street Vasile Alecsandri Street.

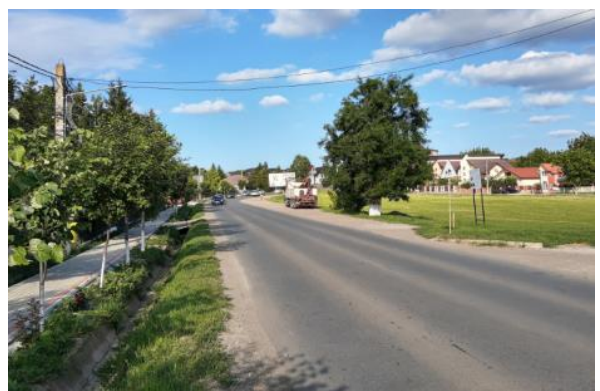

Fig. 4 - Constantin Langa Street with deleted road markings.

Constantin Langa school also operates in the area and the indicators in the area are specific to the school area, but they are degraded and difficult to see by traffic participants. There is a lack of sidewalk, and the sidewalk is used by both pedestrians and drivers to park cars (Fig. 5). On the Arhitect Beldiman Filaret Street, although regulated by no-parking signs, there are still parked 
vehicles. The vehicular load of this street is low, being used mainly by the residents of the area. Pedestrian access on this street is hampered by parked cars and the lack of a sidewalk for pedestrians. The analysed section is crossed by the means of public transport CTP route 23 (Fig. 6).

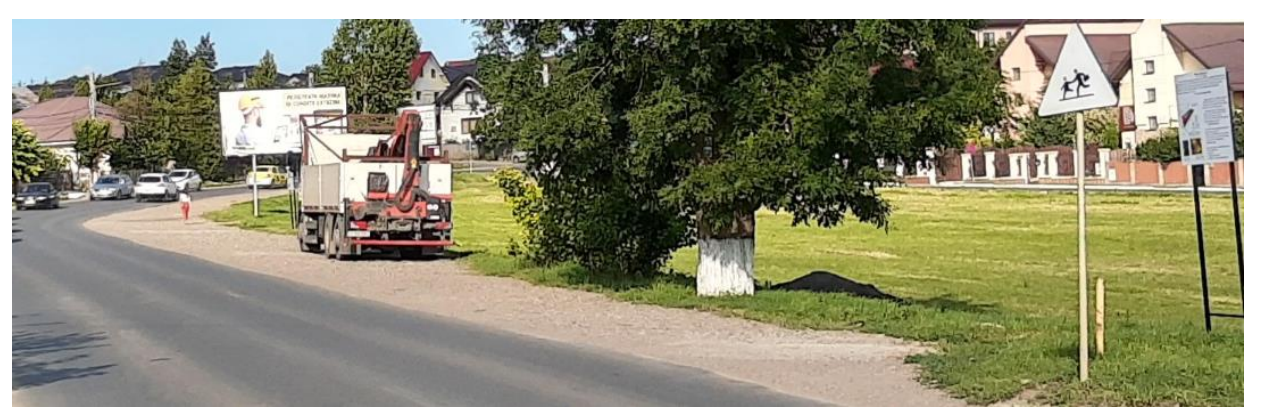

Fig. 5 - Street Constantin Langa with road markings erased.

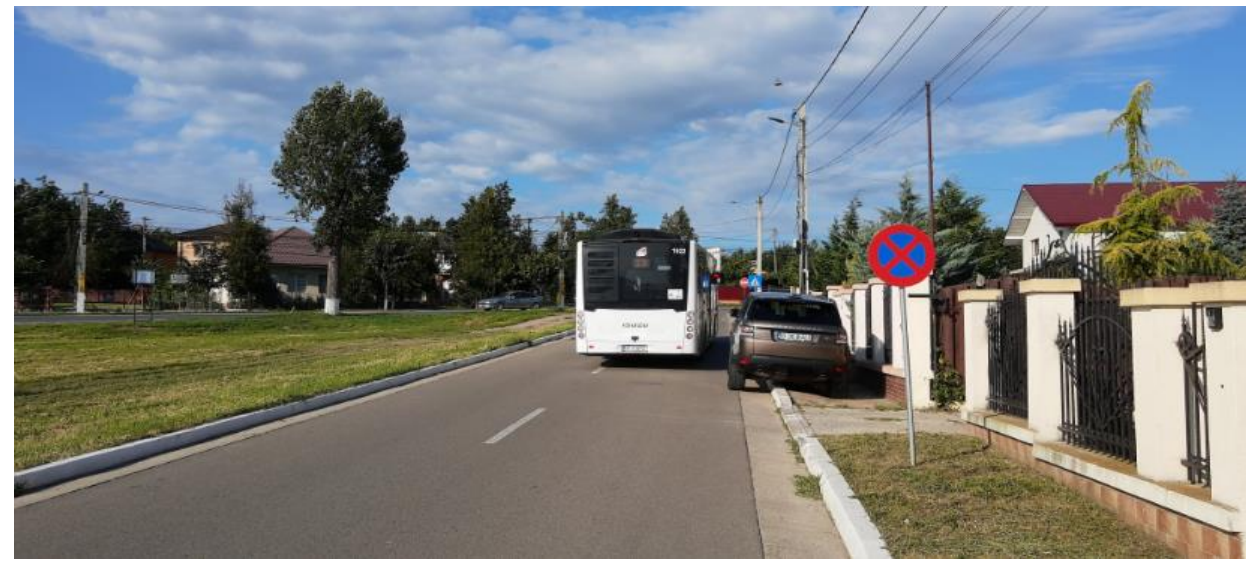

Fig. 6 - Arhitect Beldiman Filaret Street with illegal parked vehicles.

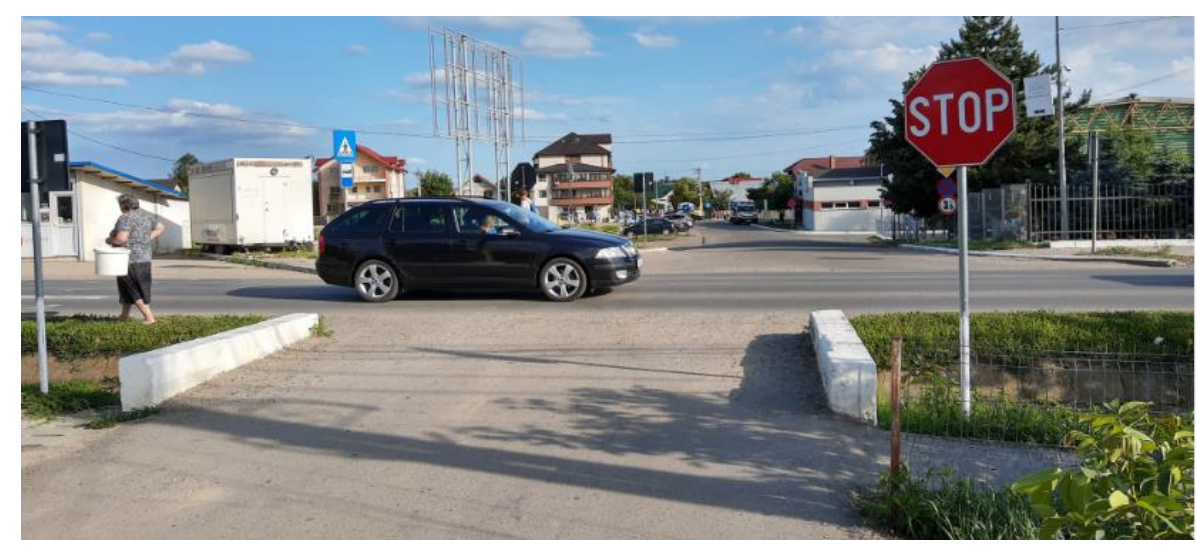

Fig. 7 - Bridge which make the traffic slower. 
In Fig. 7, on Scolii Street, it is observed that there is a bridge for the access of small vehicles $5 \mathrm{~m}$, without radius of curvature of the intersection, which generates difficulties for drivers to turn left or right on the Școlii Street.

\section{Methodology to Calculate the Traffic Capacity of the Street Intersections}

For calculation the traffic capacity of the intersections of new and existing streets is made according to the arrangement of the intersection, the traffic characteristics and the local conditions for the smooth and safe development of traffic (Maftei et al., 2016).

This calculation is used to establishing the traffic capacity of the street intersections and the traffic markets corresponding to the operation solution and the type of intersection; for dimensioning the elements of the intersection (such as the entry, crossing, bypass and exit routes from the intersection and storage spaces) which determine the circulation capacity of the assembly (HCMHighway Capacity Manual, 2000).

Based on the intersection traffic diagram, several variants of the flow organization scheme of the intersection flows can be determined, adopting the solution that minimizes the total crossing time and the volume of works (STAS 10144/6-89).

The delimitation of the intersection space is made by the markings for stopping vehicles at pedestrian crossings, or, in their absence, by the position of traffic lights near which they stop vehicles. In the common crossing space appear the limit points of conflict between vehicles and between vehicles and pedestrians, which determine the evacuation lengths of the intersection by vehicles $\left(\mathrm{d}_{\mathrm{v}}\right)$ and pedestrians $\left(\mathrm{d}_{\mathrm{p}}\right)$, respectively the times necessary for evacuation (STAS 11416-80).

Depending on the proportion of transit traffic on the traffic streets, they can be classified into: main roads, secondary roads and local roads (STAS 4032/2-73)

Table 1

Road Classes. Functionality

\begin{tabular}{||l|l|l|c|c||}
\hline \hline $\begin{array}{l}\text { Functional } \\
\text { Class }\end{array}$ & Class name & Road category & $\begin{array}{c}\text { Transit traffic } \\
{[\%]}\end{array}$ & $\begin{array}{c}\text { Local traffic } \\
{[\%]}\end{array}$ \\
\hline \hline First class & Main roads & $\begin{array}{l}\text { Highways, } \\
\text { express roads, } \\
\text { European roads, } \\
\text { main national } \\
\text { roads, bypasses }\end{array}$ & $75-95$ & $5-25$ \\
\hline Second class & $\begin{array}{l}\text { Secondary } \\
\text { roads }\end{array}$ & $\begin{array}{l}\text { Secondary } \\
\text { national roads, } \\
\text { county roads }\end{array}$ & $35-75$ & $25-65$ \\
\hline Third class & Local roads & $\begin{array}{l}\text { county roads, } \\
\text { communal roads }\end{array}$ & $5-15$ & $85-95$ \\
\hline
\end{tabular}


Close distances of intersections from each other creates problems in terms of visibility at the intersection, perception of the next intersection and implicitly adaptation to traffic conditions, anticipation of road events, observation and understanding of the meaning of road signs (Brilon et al., 1991). The density of intersections on a traffic road is determined by the speed of traffic and by the functional road class. Limiting the number of intersections on roads aims to increase traffic safety by reducing the number of potential areas of conflict, and increase traffic capacity and traffic flow by reducing the number of traffic disruptions. In Fig. 8 is presenting the minimum distances between intersections (FGSV-Merkblatt, 1998).

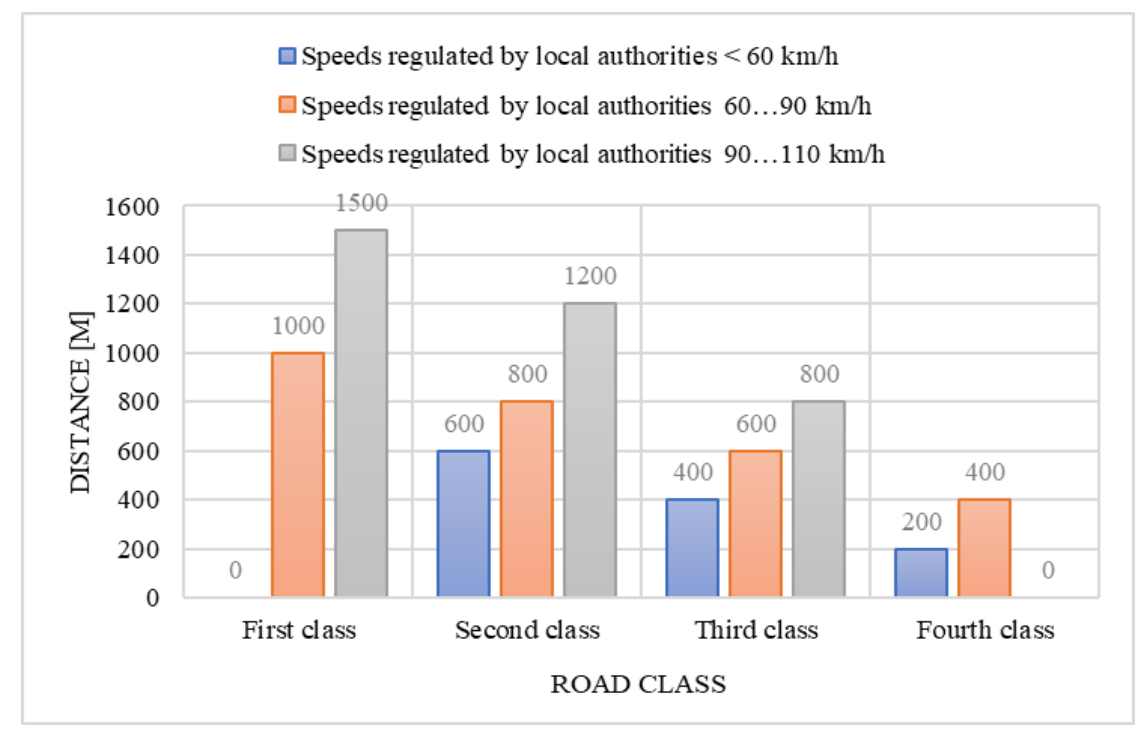

Fig. 8 - Minimum distances between intersections.

The traffic capacity and reserve capacities of the road intersections involved in taking over the traffic flows generated by the operation of the new building were determined:

- the intersection of Constantin Langa street with Vasile Alecsandri street;

- the intersection of Vasile Alecsandri Street with Architect Beldiman Filaret Street;

- the intersection of Arhitect Beldiman Filaret Street with Constantin Langa Street.

The traffic capacity of the intersection of Constantin Langa Street with Vasile Alecsandri Street.

Geometrically, the intersection is of the cross type, at right angles (at $90^{\circ}$ ), with rectilinear arms and therefore respects the minimum conditions for 
the intersection. We specify that the two sections of the Constantin Langa Street intersected are arranged in alignment. The intersection and the connected areas of the entrance / exit arms of the intersection are contained in the horizontal plane respecting the conditions of the location of the intersection in the horizontal plane. Pedestrian crossings at this intersection are provided on three of the intersected artery segments. The intersection capacity of the flows with rhythmic arrivals is established according to the succession limit intervals e, specified in Table 2 (Stuwe, 1995).

Table 2

Ability to intersect flows with rhythmic arrivals

\begin{tabular}{|c||c||}
\hline Intersection maneuver & Succession limit range, e $[\mathrm{s}]$ \\
\hline \hline Perpendicular intersection & $4.5 \div 6.5$ \\
\hline Insertion on the right & $5.0 \div 6.5$ \\
\hline Insertion on the left & $6.5 \div 8.0$ \\
\hline Flow ordering & $7.0 \div 8.5$ \\
\hline
\end{tabular}

The relationship between the average size of the succession intervals e and the intensity of the flow of vehicles $\mathrm{N}$ is the following:

$$
\mathrm{e}=\frac{3600}{\mathrm{~N}}
$$

The circulation capacity $\mathrm{N}_{t}$, at the intersection of two flows with rhythmic arrivals, $\mathrm{N}_{1}$ and $\mathrm{N}_{2}$, when the intersection manoeuvre requires a limit interval of succession between vehicles e, is established with the relation:

$$
\mathrm{N}_{\mathrm{t}}=\mathrm{N}_{1}+\mathrm{N}_{2}=\frac{3600}{\mathrm{e}} \text { [equivalent vehicles/hour] }
$$

The left insertion of the secondary flow in the main flow is the most problematic, assuming the achievement of an average succession interval between the vehicles of the total flow, having a minimum value of $\mathrm{e}=6.5$ seconds (according to the Table 2 ) and which imposes a maximum value of the total flow intensity $\mathrm{N}=3600 / 6.5=554$ equivalent vehicles/hour. From the results of the traffic study, there is a maximum hourly flow of 536 equivalent vehicles / hour (in the time interval 17-18), on Constantin Langa Street.

The maximum total flow at the left insertion of the secondary flow on Vasile Alecsandri Street in the main flow on Constantin Langa Street will therefore have the value of $268+16=284$ equivalent vehicles / hour, and 
which would ensure a minimum reserve of this intersection of 554-284 $=270$ equivalent vehicles / hour, practically double compared to the additional traffic demand induced by the new building (of 137 equivalent vehicles / hour).

\section{Filaret Street.}

The intersection of Vasile Alecsandri Street with Architect Beldiman

The intersection is of the cross type, with $90^{\circ}$ angles, with rectilinear arms and therefore respects the minimum conditions for achieving the intersection in terms of traffic safety. Intersection not raise special problems in terms of visibility, perception of the next intersection and consequent adaptation to traffic conditions, anticipation of possible road events and observation/assimilation of the significance of road signs and markings. The traffic runs in both directions on all 4 segments of intersected streets. All accesses at the intersection are provided with one lane per direction.

The capacity of the intersection will be checked from the point of view of the most difficult insertion, respectively the insertion to the left of the secondary flow (from Vasile Alecsandri Street) in the main one (of Arhitect Beldiman Filaret Street). From the results of the traffic study, there are maximum hourly flows of 32 equivalent vehicles/hour on Vasile Alecsandri Street and, respectively, 125 equivalent vehicles/hour on Arhitect Beldiman Filaret Street. The left entry of the secondary flow rate in the main flow rate is the most problematic, assuming the achievement of an average succession interval between the vehicles of the total flow rate, having a minimum value of $\mathrm{e}=6.5$ seconds (according to Table 2 ) and which imposes a maximum intensity value $\mathrm{N}=3600 / 6.5=554$ equivalent vehicles/hour.

The maximum total flow at the left insertion of the secondary flow on Vasile Alecsandri Street in the main flow on Arhitect Beldiman Filaret Street, will therefore have the value $125+32=157$ equivalent vehicles/hour and which would ensure a minimum reserve of this intersection of 554-157=397 equivalent vehicles/hour, practically three times higher than the additional traffic demand induced by the new building (of 137 equivalent vehicles/hour).

\section{Langa Street.}

The intersection of Arhitect Beldiman Filaret Street with Constantin

The intersection is defined by the geometric junction, in $\mathrm{T}$, without traffic lights, directed by road signs, of Arhitect Beldiman Filaret Street with Constantin Langa Street (main road).

The left insertion of the secondary flow in the main flow is the most problematic, assuming the achievement of an average succession interval between the vehicles of the total flow having a minimum value of $\mathrm{e}=6.5$ seconds (according to Table 2) and which imposes a maximum value of the flow intensity with a total $\mathrm{N}=3600 / 6.5=554$ equivalent vehicles/hour. From the results of the traffic study, there is a maximum hourly flow of 125 
equivalent vehicles/hour on Arhitect Beldiman Filaret Street. The maximum flow measured on Constantin Langa Street has the value of 536 equivalent vehicles/hour, with an average of 268 equivalent vehicles/hour. The maximum total flow at the left insertion of the secondary flow on Arhitect Beldiman Filaret Street in the main flow on Constantin Langa Street, will therefore have the value of $268+125=393$ equivalent vehicles / hour, and which would ensure a minimum reserve of this intersection of 554-393=161 equivalent vehicles/hour, higher than the additional traffic demand induced by the new objective (of 137 equivalent vehicles/hour).

\section{Results of the Traffic Measurements}

Due to the fact that during the elaboration of this traffic study in Romania was declared a state of alert, for real-time road traffic monitoring the vehicle census was made it with the help of video cameras. The traffic data obtained were processed and the vehicles were divided according to the regulations into vehicles/hour.

Figs. 9-11 show the census points, respectively the place where the video cameras monitored the road traffic.

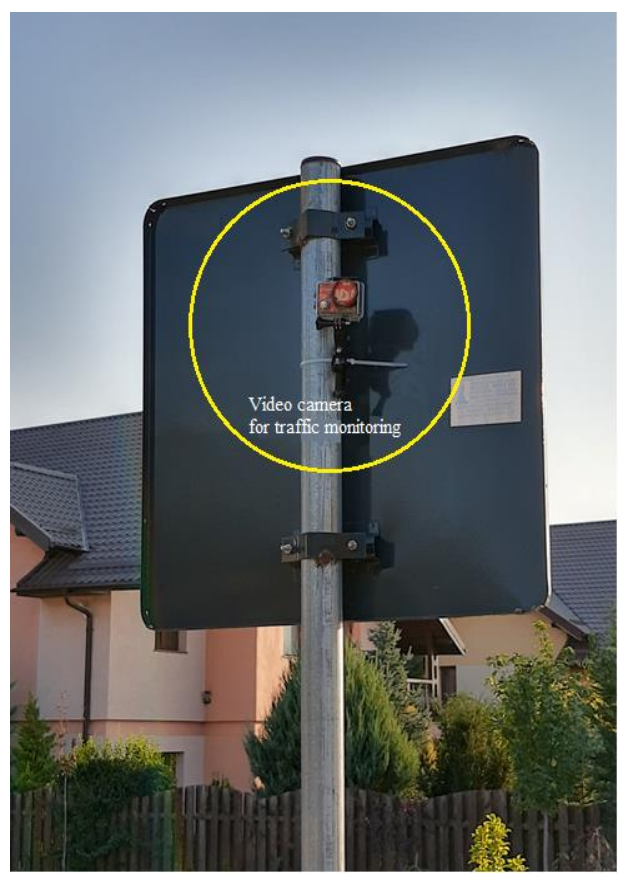

Fig. 9 - Video camera for traffic monitoring.

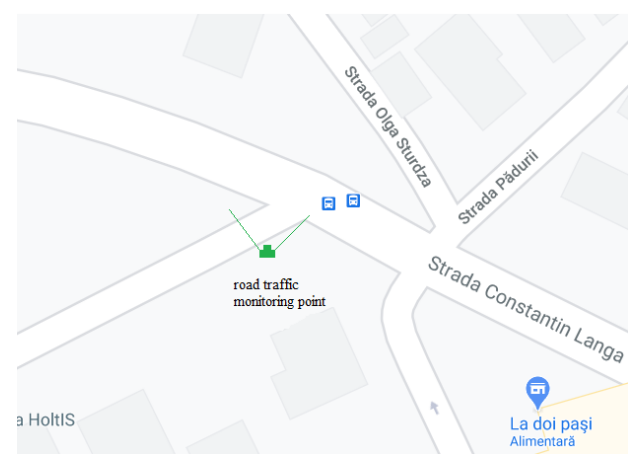

Fig. 10 - Road traffic monitoring point.

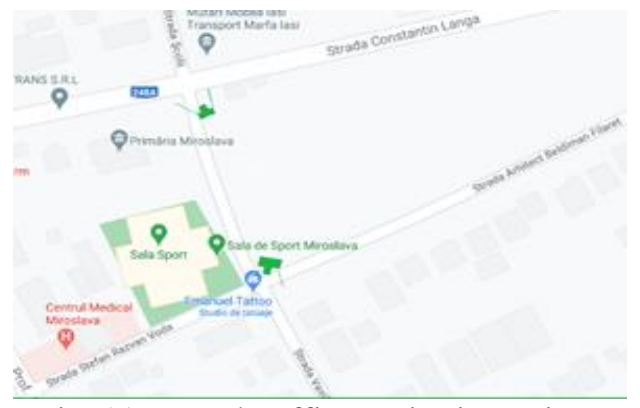

Fig. 11 - Road traffic monitoring points. 
The traffic measurements captured the normal traffic situation, within the limits provided by STAS 10144 / 5-89. According to STAS 10795 / 1-76 Road traffic technique. Traffic investigation methods. Classification - the main characteristics of road traffic that are determined by traffic investigation are: traffic intensity and density, traffic flows and composition, characteristics of traffic currents, traffic speed and average speed of vehicles traveling alone or in groups, succession interval and the space between consecutive vehicles.

The measurements took place between peak hours, when traffic values are maximum, respectively in the morning between $7 \mathrm{AM}$ and $9 \mathrm{AM}$ and in the afternoon between 5 PM and 7 PM. During the measurements, there were no accidents blocking road traffic and the weather conditions were favourable for traffic throughout the recordings. No other circumstances (local concentration of pollutants, other unfavourable conditions) were created to alter or invalidate the measurement results. The traffic measurements were performed simultaneously on all the arteries of the road network near the building: Constantin Langa Street (Voineşti - Iaşi road), Vasile Alecsandri Street, Arhitect Bediman Filaret Street, as well as the intersections of these streets.

The intersection between Constantin Langa Street and Vasile Alecsandri Street.

All the flows of vehicles entering and leaving this intersection were measured, the car traffic directions being represented in Fig. 12.

In Fig. 13a, $b$ it can been seen the hourly graphic of vehicles traveling through the intersection on each flow on the peak hours.

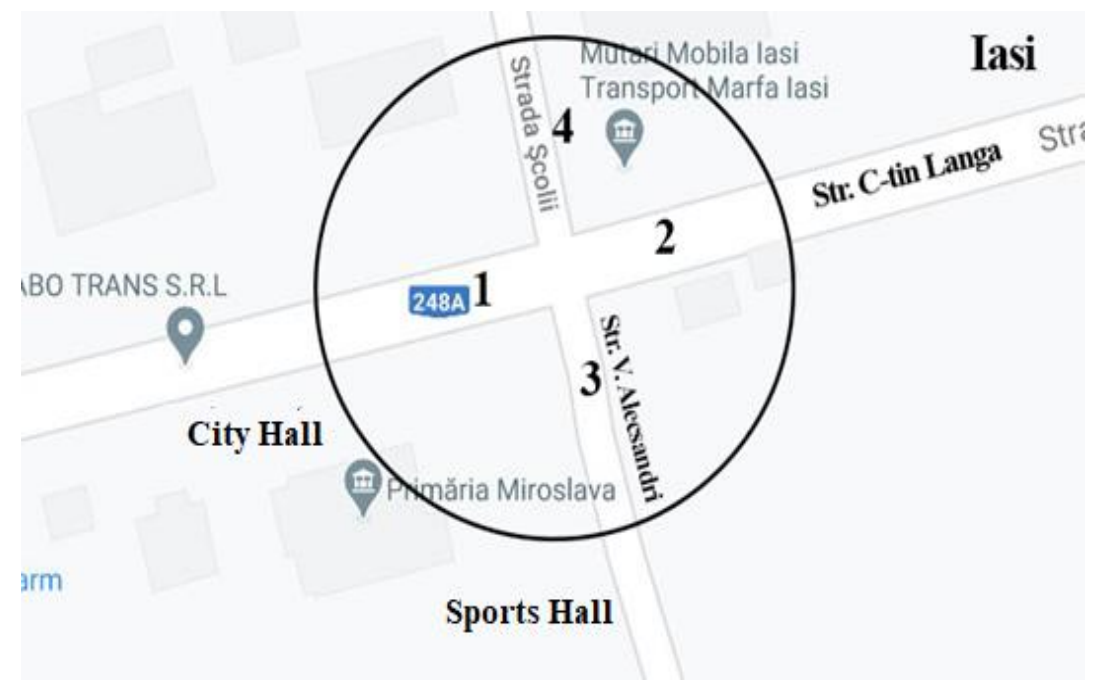

Fig. 12 - Numbering of vehicle flows at the intersection Constantin Langa - Vasile Alecsandri streets. 


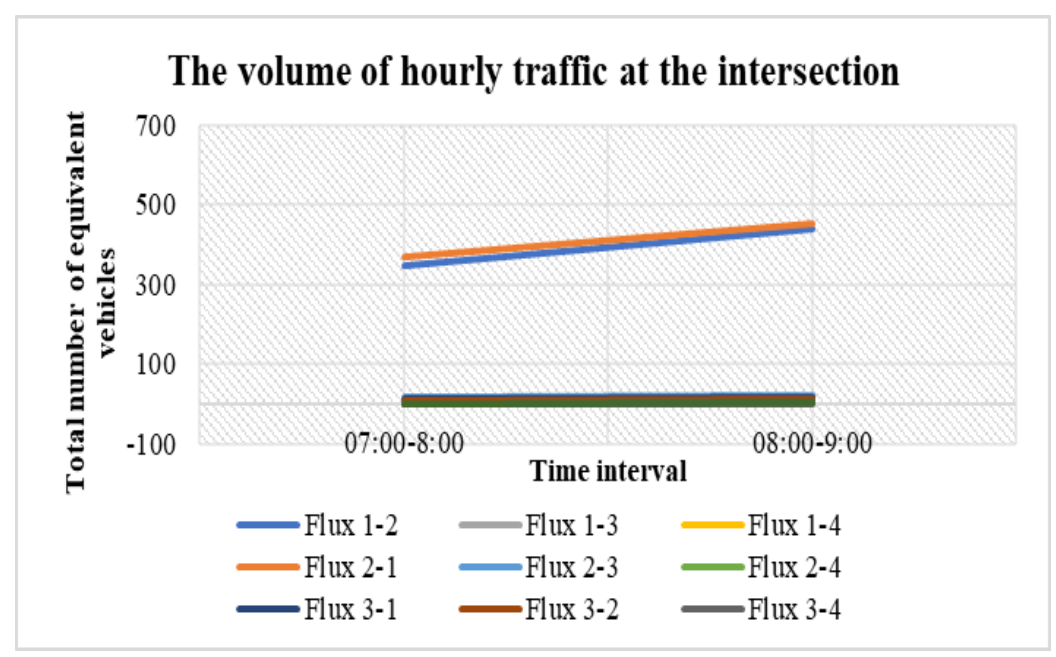

Fig. 13a-Hourly traffic volume at the intersection of Constantin Langa and Vasile Alecsandri streets - 7 AM - 9 AM.

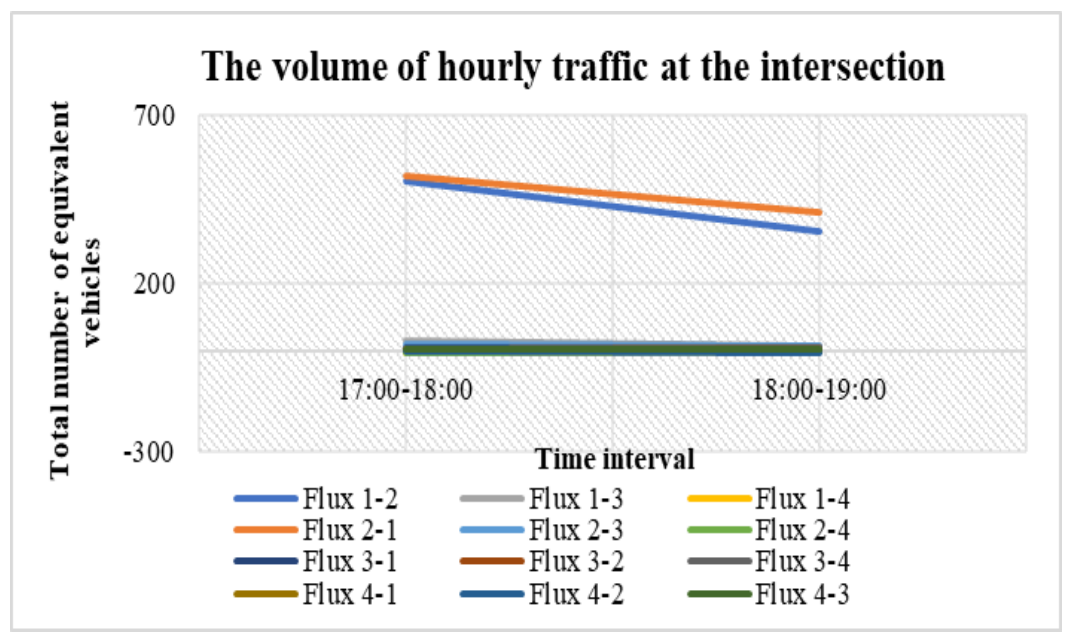

Fig. 13b - Hourly traffic volume at the intersection of Constantin Langa and Vasile Alecsandri streets - 5 PM - 7 PM.

The intersection between Vasile Alecsandri Street and Arhitect Beldiman Filaret Street.

All the flows of vehicles entering and leaving this intersection were measured, the car traffic directions being represented in Fig. 14.

In Fig. $15 a, b$ it can been seen the hourly graphic of vehicles traveling through the intersection on each flow on the peak hours. 


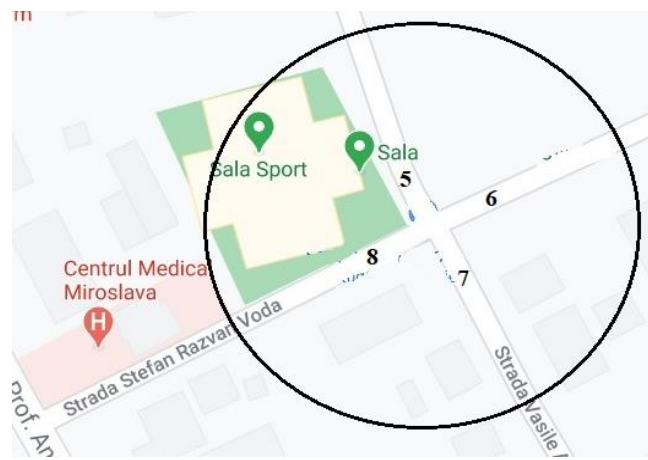

Fig. 14 - Numbering of vehicle flows at the intersection Vasile Alecsandri and Arhitect Beldiman Filaret streets.

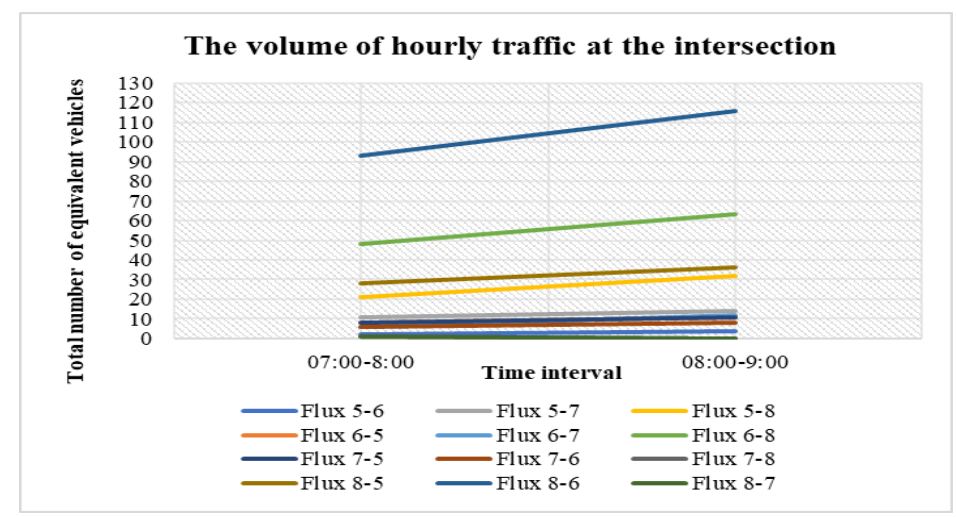

Fig. 15a-Hourly traffic volume at the intersection of Vasile Alecsandri and Arhitect Beldiman Filaret streets - 7 AM - 9 AM.

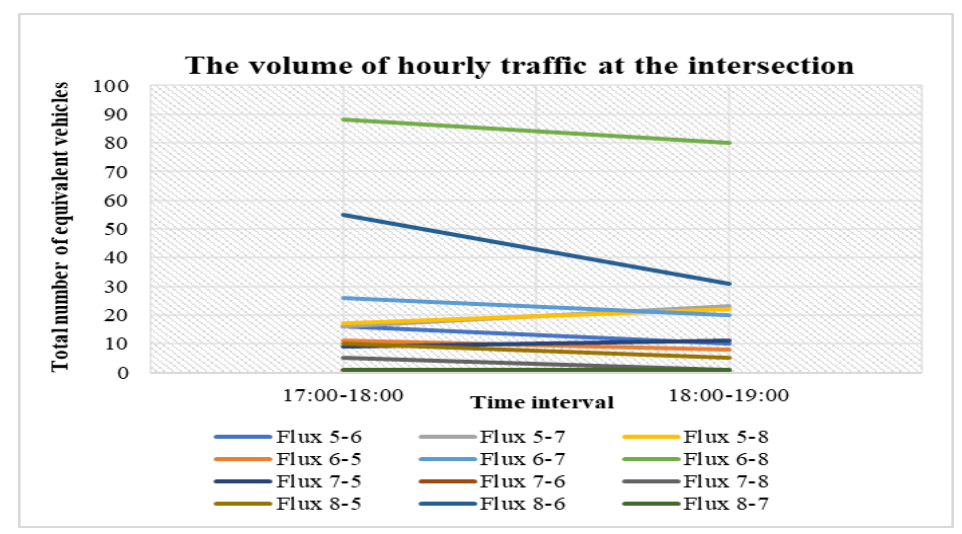

Fig. 15b- Hourly traffic volume at the intersection of Vasile Alecsandri and Arhitect Beldiman Filaret streets - 5 PM - 7 PM. 
The intersection between Constantin Langa Street and Arhitect Beldiman Filaret Street.

All the flows of vehicles entering and leaving this intersection were measured, the car traffic directions being represented in Fig. 16.

In Fig. 17a, $b$ it can been seen the hourly graphic of vehicles traveling through the intersection on each flow on the peak hours.

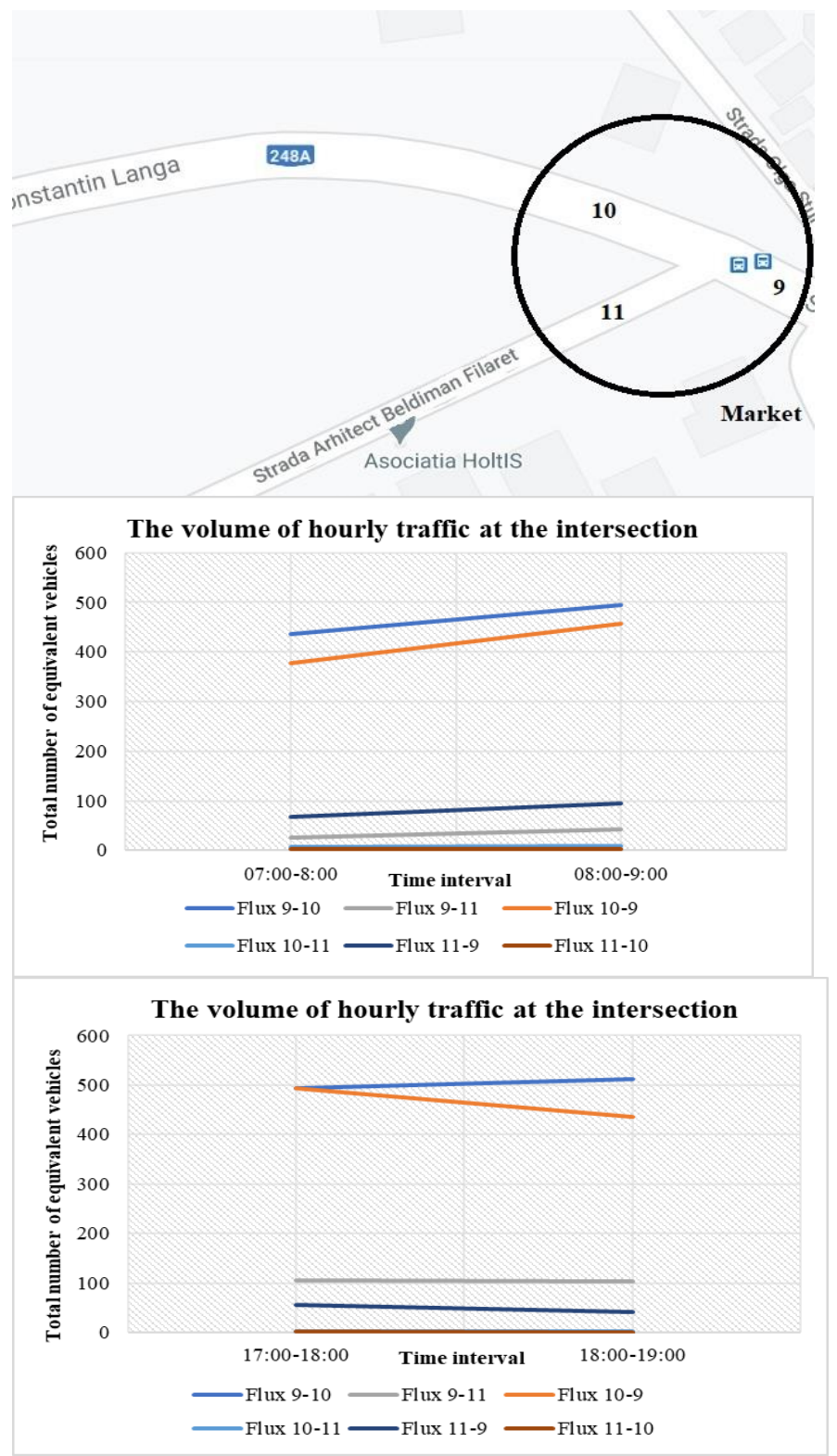

Fig. 16 - Numbering of vehicle flows at the intersection Vasile Alecsandri and Arhitect Beldiman Filaret streets.

Fig. 17a-Hourly traffic volume at the intersection of Vasile Alecsandri and Arhitect Beldiman

Filaret streets -

$7 \mathrm{AM}-9 \mathrm{AM}$.

Fig. 17b-Hourly traffic volume at the intersection of Vasile

Alecsandri and Arhitect Beldiman

Filaret streets -

5 PM - 7 PM. 


\section{Conclusions}

The flows of vehicles and pedestrians will be increased in the area by the new real estate construction, raising new issues regarding the connection to the road network and the road traffic of the village. Traffic management solutions cover three aspects: vehicle traffic, pedestrian traffic, and the placement of road signs and markings.

The section of the street from Constantin Langa Street (Iaşi-Voineşti road) adjacent to the investment, in present, allows the smooth running of the road traffic. From the intersection of Vasile Alecsandri Street with Școlii Street till the intersection of Constantin Langa Street with Arhitect Beldiman Filaret Street, it is proposed to widen the road (at $12.7 \mathrm{~m}$ ) to facilitate the arrangement of two lanes each way as well as the sidewalk for pedestrians. The traffic reorganization proposal aims is to arranging the intersection without traffic light signals. To get out of the building on Vasile Alecsandri Street, it is proposed to create an additional lane for turning right and a dedicated lane for going forward and left.

Framing of vehicle flows attracted/generated by the location of new investment, estimated assuming the disadvantage - considering that all clients move from/to the building by road network at the same time slot busiest both in the morning and in the afternoon, that can be done without any problems. The proposed measures for the arrangement of the street network and for the organization of the traffic ensure the taking over of the traffic attracted/generated by the new investment, even at peak hours.

\section{REFERENCES}

Brilon W., Stuwe B., Kreisverkehrplaetze - Leistungfaehigkeit, Sicherheit und verkehrstechnische Gestaltung, Strassenverkehrstechnik, 6 (1991).

Dontu A.I., Maftei A., Barsanescu P.D., Sachelarie A., Budeanu B., Method of Preventing Unwanted Traffic in the "Tudor Vladimirescu" University Campus, IOP Conf. Series: Materials Science and Engineering (2016).

Maftei A., Dontu A.I., Sachelarie A., Budeanu B., Method of Creating Additional Parking Spaces in the "Tudor Vladimirescu" University Campus, IOP Conf. Series: Materials Science and Engineering (2016).

Stuwe B., Geschichte der Kreisvekehrplaetze und ihrer Berechnugsverfahren, Stassenverkehrstechnik, 39, 12 (1995).

** FGSV-Merkblatt fur die Anlage von kleinen Kreisverkehrplaetzen, FGSV, Cologne, (1998).

** HCM-Highway Capacity Manual-Transportation Research Board, Special Report no.209, (2000).

$* *$ https://www.walterpmoore.com/traffic-studies - accessed on 25.10.2020.

** https://www.ite.org/pub/?id=e2652bd6-2354-d714-5149-580789217232. 
$*^{*} *$ STAS 4032/2-73 - Tehnica traficului rutier. Terminologie.

$* *^{*}$ STAS 11416-80 - Tehnica traficului rutier. Capacitatea de circulatie a drumurilor.

$*{ }_{*}^{*}$ STAS 10144/6-89 - Calculul capacității de circulație a intersecțiilor de străzi.

\section{STUDIU DE TRAFIC PRIVIND INFLUENTTA ZONEI DE CONSTRUCȚIE IMOBILIARĂ CU FUNCȚII MIXTE}

\section{(Rezumat)}

Scopul principal al acestei lucrări a fost de a analiza impactul unei clădiri nou construite asupra traficului auto şi pietonal dintr-un sat puternic industrializat și în plină creștere demografică, din zona metropolitană a orașului Iași. Clădirea influențează dinamica traficului rutier în zona adiacentă investiției, iar integrarea acesteia din punct de vedere al traficului rutier impune adoptarea unor soluții de creșterea siguranței rutiere şi metode de fluidizare a traficului. 